\title{
Development of HTLV-1 associated myelopathy/ tropical spastic paraparesis in a patient with simian T-lymphotropic virus type 1-like infection.
}

\author{
Yoshimi Enose-Akahata', Breanna Caruso', Benjamin Haner ${ }^{1}$, Raya Massoud ${ }^{1}$, Bridgette Jeanne Billioux', \\ Joan Ohayon', William M Switzer², Steven Jacobson ${ }^{1 *}$
}

From 17th International Conference on Human Retroviruses: HTLV and Related Viruses

Trois Ilets, Martinique. 18-21 June 2015

Virus transmission from various wild and domestic animals contributes to increased risk of emerging infectious diseases in human populations. HTLV-1 is a human retrovirus associated with acute T-cell leukemia (ATL) and HTLV-1-associated myelopathy/tropical spastic paraparesis (HAM/TSP), which originated from zoonotic transmission from various African and Asian nonhuman primates (NHPs). Similar to HTLV-1, the simian counterpart, STLV-1, causes chronic infection and leukemia and lymphoma in naturally infected monkeys. However, other clinical syndromes typically seen in human such as a chronic progressive myelopathy have not been observed in NHPs. Little is also known about the development of any neurologic and inflammatory diseases in human populations infected with STLV-1-like viruses following NHP exposure. We identified and analyzed the complete genome of a primate $\mathrm{T}$ lymphotropic virus type 1 (PTLV-1) isolated from a patient with typical HAM/TSP who resides in the United States but was born in Liberia. Using a novel droplet digital PCR for the detection of the HTLV-1 tax gene, the proviral load in PBMC was $14.01 \%$; however there was a distinct difference in fluorescence amplitude compared to all other H!M/TSP patient's, suggesting viral heterogeneity. A complete PTLV-1 proviral genome was amplified from DNA extracted from the PBMCs of the HAM/TSP patient using PCR to generate nine overlapping subgenomic fragments. Phylogenetic analysis of PTLV-1 env and LTR regions showed the virus was highly related

\footnotetext{
* Correspondence: jacobsons@ninds.nih.gov

'Viral Immunology Section, Neuroimmunology Branch, National Institute of Neurological Disorders and Stroke, National Institutes of Health, Bethesda, MD, USA

Full list of author information is available at the end of the article
}

with PTLV-1 from sooty mangabey monkeys and humans exposed from NHPs in West Africa. These results suggest the patient is likely infected with STLV1 , suggesting for the first time that viral transmission from monkey to human may be associated with a chronic progressive neurologic disease.

\section{Authors' details}

'Viral Immunology Section, Neuroimmunology Branch, National Institute of Neurological Disorders and Stroke, National Institutes of Health, Bethesda, MD, USA. ${ }^{2}$ Laboratory Branch, Division of HIV/AIDS, National Center for HIV, Hepatitis, STD, and TB Prevention, Centers for Disease Control and Prevention, Atlanta, GA 30329, USA.

Published: 28 August 2015

\section{doi:10.1186/1742-4690-12-S1-030}

Cite this article as: Enose-Akahata et al: Development of HTLV-1 associated myelopathy/tropical spastic paraparesis in a patient with simian T-lymphotropic virus type 1-like infection.. Retrovirology 2015 12(Suppl 1):O30.

Submit your next manuscript to BioMed Central and take full advantage of:

- Convenient online submission

- Thorough peer review

- No space constraints or color figure charges

- Immediate publication on acceptance

- Inclusion in PubMed, CAS, Scopus and Google Scholar

- Research which is freely available for redistribution 